\title{
WHO strengthens Zika travel advice to pregnant women
}

\author{
Anne Gulland
}

London

The World Health Organization has strengthened its advice to pregnant women, urging them not to travel to areas where the Zika virus is circulating.

The advice, issued after the second meeting of WHO's emergency committee convened under the International Health Regulations, was issued in the light of stronger evidence of an association between the virus and fetal malformations.

Previously, WHO had said that pregnant women should take precautions against mosquito bites if travelling to areas affected by Zika. ${ }^{1}$

Margaret Chan, WHO director general, told a press conference after the meeting on 8 March that the virus had been detected in amniotic fluid and had been shown to cross the placental barrier and infect the fetus. The virus has been detected in the blood, brain tissue, and cerebrospinal fluid of fetuses after miscarriage, stillbirth, or termination of pregnancy.

Chan said, "Microcephaly is now only one of several documented birth abnormalities associated with Zika infection during pregnancy. Grave outcomes include fetal death, placental insufficiency, fetal growth retardation, and injury to the central nervous system." She added that studies of miscarriages and stillbirths had shown that the virus did not attack other organs.

David Heymann, chair of the emergency committee, said that the strengthened travel advice did not apply to whole countries.

"This is about areas of ongoing Zika virus outbreaks," he said. "The onus is on the countries to identify and report where they have an outbreak, and then it's up to pregnant women or women planning to conceive to decide based on the information given to them. It's not country-wide advice-it's about areas of ongoing transmission."

The committee said that research into the relationship between new clusters of microcephaly, neurological disorders, and the Zika virus should be intensified. It also said that work should begin on developing a case definition for "congenital Zika infection."
Local transmission of the virus has been reported in 31 countries in Latin America and the Caribbean. An increase in the number of microcephaly cases has been reported in Brazil and French Polynesia, and nine countries have reported an increase in the number of cases of Guillain Barré syndrome. No deaths have occurred from Guillain Barré syndrome, but patients often need to be treated in intensive care because they need ventilation. This adds a "further burden on health systems," said Chan.

Colombia is on the alert for an increase in fetal malformations, as the virus was first reported there in October last year. Heymann said, "What we see in Brazil could occur in Colombia and other countries in the next few months. It's very alarming." Chan said that the Colombian minister of health had given a detailed presentation on the number of cases of dengue, Zika, and chikungunya - all spread by the same vector, the Aedes aegypti mosquito. "It's not so easy to distinguish between them because they all happen at around the same time and in terms of testing they are cross reactive," she said.

Chan also urged countries and other donors to help with the response to the virus, after she revealed that just $\$ 3 \mathrm{~m}(£ 2.11 \mathrm{~m}$; $€ 2.74 \mathrm{~m}$ ) of the requested $\$ 56 \mathrm{~m}$ had been received for its Zika response plan. ${ }^{2}$

"We encourage countries to support this important work. It's easy for us to say we will do our utmost, but financing of the work is important," she said.

For The BMSs latest articles on the Zika virus epidemic go to bmj.co/ zika.

Torjesen I. Zika virus outbreaks prompt warnings to pregnant women. BMJ 2016;352:1500 McCarthy M. WHO sets out \$56m Zika virus response plan. BMJ 2016;352:11042.

Published by the BMJ Publishing Group Limited. For permission to use (where not already granted under a licence) please go to http://group.bmj.com/group/rights-licensing/ permissions 